\title{
Futómű alkatrészek (lengőkar és stabilizátor rúd) maradó feszültségének meghatározásához szükséges BHN vizsgálati berendezés tervezése és megvalósítása Design and Implementation of BHN Testing Equipment To Measure Remaining Stress Of Wheelset Parts (Tie Rod and Stabilizer Bar)
}

\author{
G. BALOGH ${ }^{1}$, L. P. DA SILVA ${ }^{2}$ \\ ${ }^{1}$ mestertanár, Debreceni Egyetem, Műszaki Kar, Gépészmérnöki Tanszék, 4028 Debrecen, Ótemető u. 2-4., e-mail: \\ balogh.gabor@eng.unideb.hu \\ ${ }^{2} \mathrm{MsC}$ hallgató, Viçosa Federal University, Avenue Prof. Peter Henry Rolfs, Main Campus, Viçosa (MG) - Brazil, e- \\ mail: lucasarierep@gmail.com
}

\begin{abstract}
Absztrakt. Napjaink gépjármú iparában gyártói - , és szerviz oldalról is fontos igény az adott alkatrészek várható élettartamának rendkívül precíz meghatározása. Ennek módja jelenleg a rendelkezésre álló tekintélyes elméleti tudástár felhasználása mellett a müszaki gyakorlatból és gyártási-, felhasználási tapasztalatokból álló tudásbázis alkalmazása. Anyagtudományi, és törésmechanikai aspektusból ez a terület ma már kellőképpen lefedettnek tekinthető. Azonban a maradó feszültségek, melyek additívan keletkeznek már az alapanyag gyártás lépéseinél, valamint az esetleges további mechanikai alakítások, és hőkezelések, felületkezelések során, jelenleg nem megfelelően elkülöníthetők. Ennek technológiai vizsgálataira több párhuzamos fizikai módszer létezik, melyek alkalmazhatósága mindig a gyártómü döntésén, az ott dolgozó mérnökök tapasztalataira építve valósul meg. Ez a terület tehát még nem egyértelmüen szabványosított így még vállalaton belül is adódhatnak eltérések egy-egy módszer megítélése kapcsán.
\end{abstract}

\begin{abstract}
Nowadays in the automotive industry both production and service, requires accurate lifetime calculations. Today we have big amount of theoretical background and nowadays the importancy of technical and industrial databases become more and more important. By materials scientific and fracture mechanics aspects are well covered, but the remaining stresses which are present in every step of production, we can not clearly identify the origin of them. There are different paralell methods to mesure them, but the application of different methods are depending on the engineers, and their expreiences at the company. This part of the analysis is not standardised yet, so there are differences even in the same company.
\end{abstract}

Kulcsszavak: Barkhausen-zaj vizsgálat, járműipar, anyagvizsgálat, mérőberendezés. 


\section{Bevezetés}

Az anyagban lévő maradó feszültségek meghatározásának egyik módja a Barkhausen Zajjal történő vizsgálat (későbbiekben BHN), mely akár a különböző technológiai lépések (alakítás, hőkezelés, felületkezelés) közé is beiktatható. Ennek köszönhetően az autóipari gyártási folyamatokban beépíthetőek az APQP (Advanced Product Quality Planning) dokumentációs folyamatába, és a vizsgálat eredményei 100\%-ban hozzájárulnak az FMEA (Failure Mode and Effect Analisys) mátrix lehető legpontosabb meghatározásához, egyszersmind kritérium bázist létrehozva. Cikkünkben elsősorban futómű alkatrészekből (lengőkar és stabilizátor) kivett próbatestek Charpy féle vizsgálatához kapcsolható BHN méréseivel foglalkozunk. A mérőberendezésre installált BHN fej és az ahhoz tartozó mérőrendszer elkészítését ismertetjük. A Barkhausen-zaj (BHN) vizsgálat alapja, az a zajlavina, amely a ferromágneses anyagokat érő mechanikai hatások kiváltotta mágneses domain mozgások hatására jelenik meg [1]. Ez a roncsolásmentes módszer alkalmas az anyagok maradófeszültségének jellemzésére, hőkárosodások valamint a kifáradás diagnosztizálására is[4].

\section{Távoli hozzáférés az anyagvizsgáló eszközhöz}

Jelen munkánk célja egy olyan algoritmus kifejlesztése volt, mely grafikus nyelvet használ és képes nem csak a szenzorokból származó eredmények olvasására és írására, hanem a Charpy tesztberendezés vezérlésére is, biztosítva a felhasználó biztonságát. Az algoritmust LabVIEW-ban hoztuk létre, alapvetően két részből építettük fel, az első rész a berendezés távirányításáért felelős, a második rész a szenzorokból származó jelek gyűjtését, adatkezelését és feldolgozását végzi el, majd egy fájlban el is tárolja azt a későbbi felhasználhatóság végett. A modulok felépítése az 1. ábrán látható.

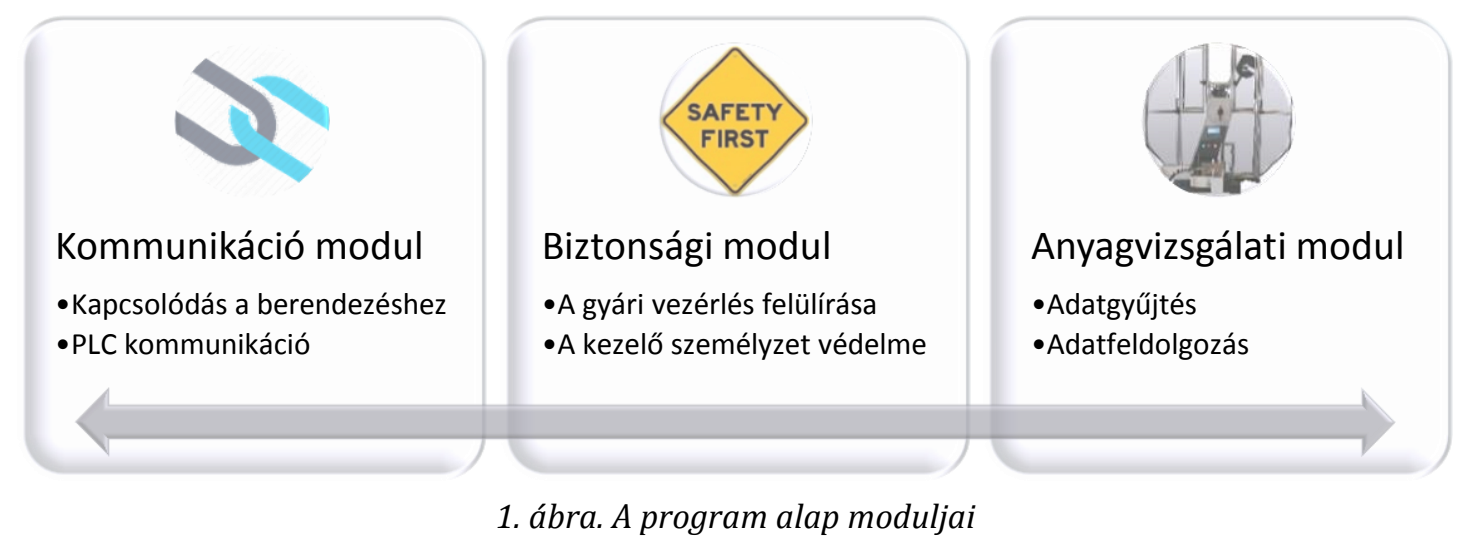

A kommunikációs modul legfontosabb feladata, hogy az anyagvizsgáló berendezés teljes vezérlését biztosítsa. A Labview és az ütőmű PLC vezérlője közti kommunikációs kódokat utasításba foglalva ezeket az utasításokat egy panelre felfüzve (1) láthatjuk az programtechnikai 2. ábrán. A csoport komplexitása miatt egy digitális gombot volt szükséges beiktatni a programba, ezt az ábra (2) részén találjuk. A (3) jelű VISA kommunikációval oldottuk meg az átvitelt. A (4) és (5) jelű egyégek felelősek a két sávos kommunikációért. A (6) egységgel zárhatjuk a kommunikációt, kizárva ezáltal az anyagvizsgáló berendezés eredeti kezelőfelületét. A (7) rész akkor jut szerephez, amikor valamilyen hiba történik. 


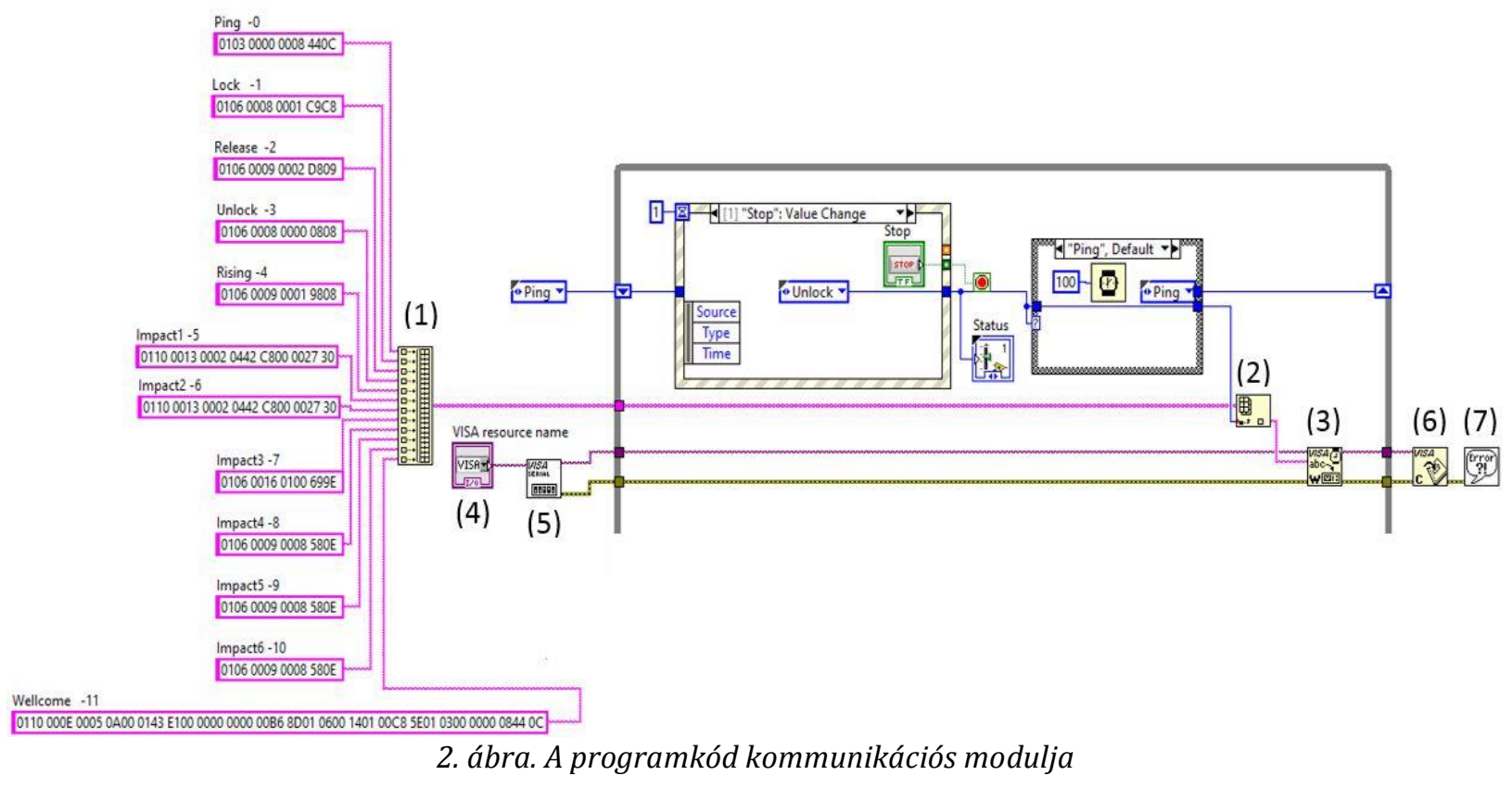

\section{Program felépítése}

Két DAQ adatgyűjtést használunk. Az első modul gyűjti az optikai kapu, a feszültségi adatokat az ütőélről valamint a Barkhausen zajt. A második modul pedig az ütőél szögelfordulásának adatait gyűjti. A modul bontása azért volt szükséges, hogy megfelelő pontossággal (minél nagyobb mintavételezési frekvencia) tudjuk a jeleket gyűjteni.

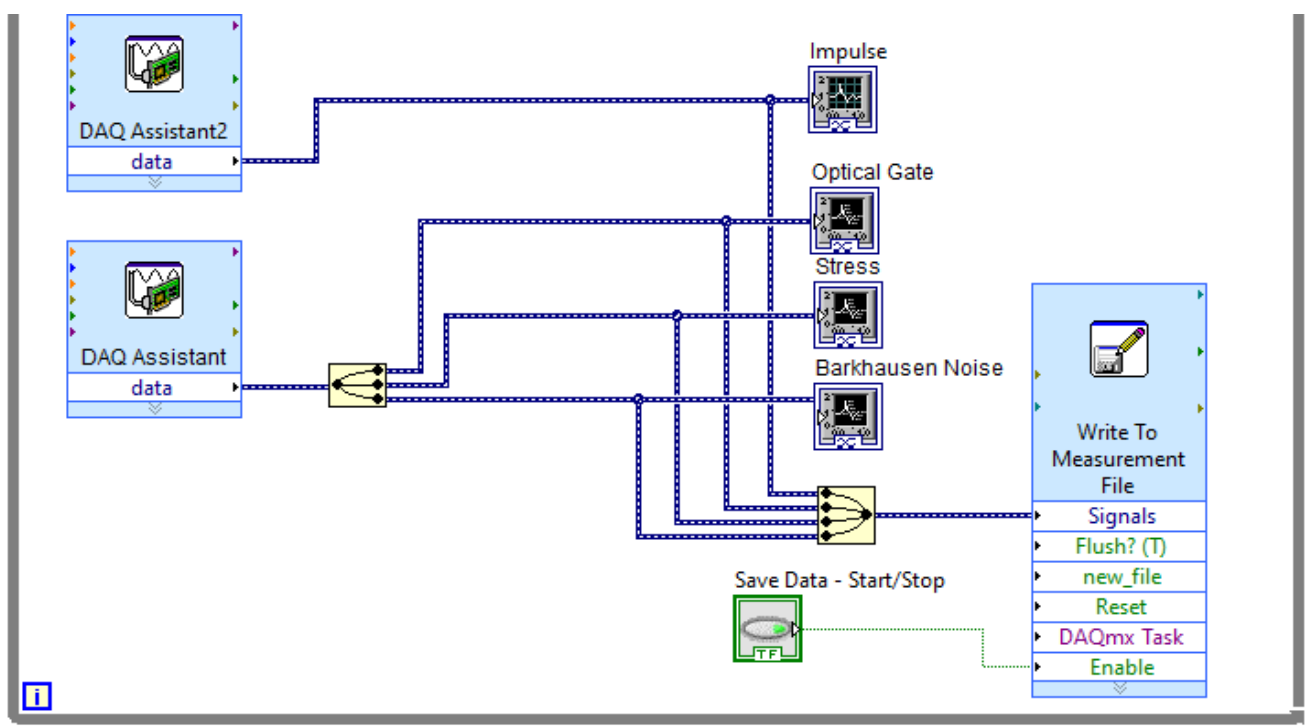

3. ábra. Az adatfeldolgozás Labview blokk diagramja 
International Journal of Engineering and Management Sciences (IJEMS) Vol. 5. (2020). No. 2

DOI: 10.21791/IJEMS.2020.2.37.

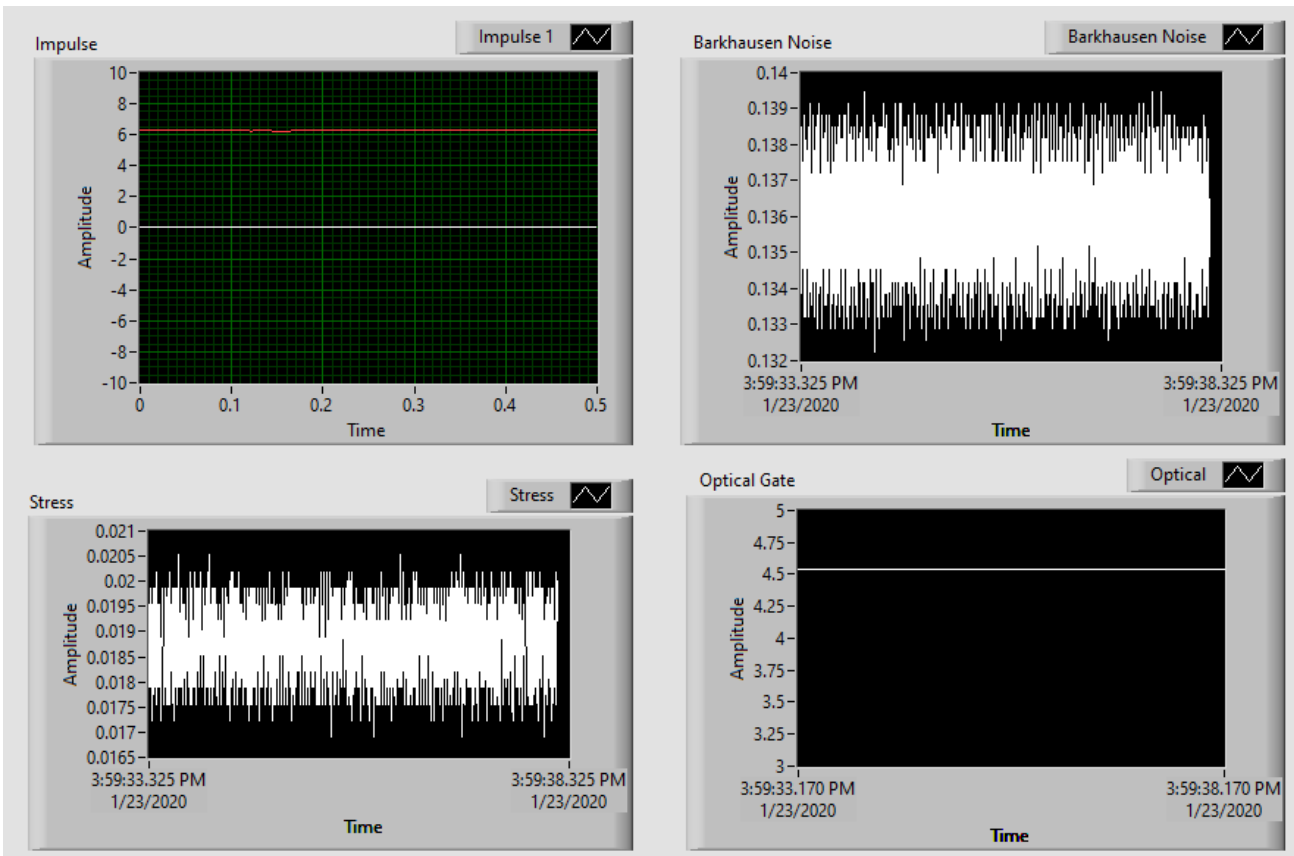

4. ábra. A méréshez gyüjtött jelek Labview diagramjai adatgyưjités közben

\section{Eredmények}
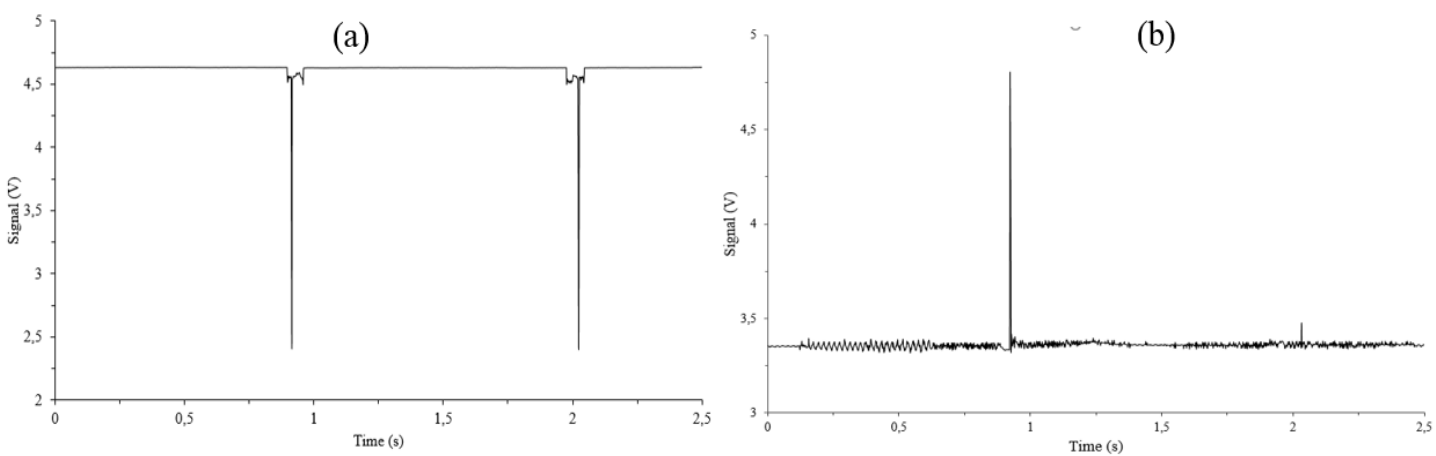

5. ábra. Optikai kapu jele (a) Barkhausen zaj (b)

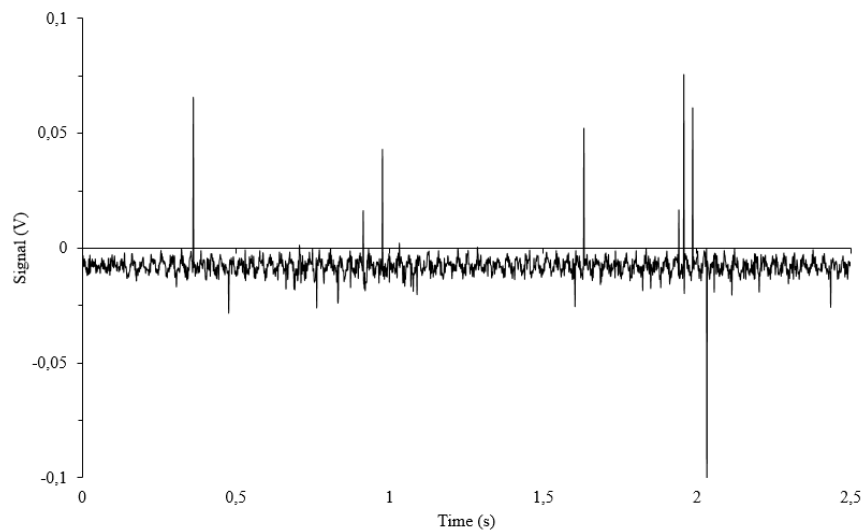

6. ábra. Feszültség jel az ütőélről 


\section{Összefoglalás}

Jelen cikkünkben a Debreceni Egyetem Műszaki Karának Gépészmérnöki Tanszékén végzett hosszú távú kutatómunka részeredményét publikáljuk. Jelen eredmények ismeretében célorientált vizsgálatokat tudunk végezni a jövőben adott gépelemek, jármű- és repüléstechnikai alkatrészek élettartam becsléséhez. A berendezést további szenzorokkal kívánjuk bővíteni, melyek segítségével további értékes adatokat nyerhetünk az anyagvizsgálatokból.

\section{Köszönetnyilvánítás}

A tanulmány alapjául szolgáló kutatást az Innovációs és Technológiai Minisztérium által meghirdetett Tématerületi Kiválósági Program ED_18-1-2019-0028 számon támogatta, a Debreceni Egyetem (Járműipar) tématerületi programja keretében.

\section{Hivatkozások}

[1] Sorsa (2013) Prediction of material properties based on nondestructive Barkhausen noise measurement. University of Oulu, Acta Universitatis Ouluensis. C, Technica, Issue: 442, ISBN: 978-952-62-0068-2, Retrieved from http://jultika.oulu.fi/files/isbn9789526200682.pdf

[2] Gábor Balogh, István Szabó (2013) Stress Dependent Rotated Magnetic Field BHN Measuring. Acta Physica Debrecina. 47(13) pp. 13-20.

[3] P. N. Mix (2005) Introduction to Nondestructive Tests - A Training Guide. 2nd ed., John Wiley \& Sons, New York.

[4] W. D. Callister (2010) Material Science and Engineering. 8th ed., John Wiley \& Sons, New York. 